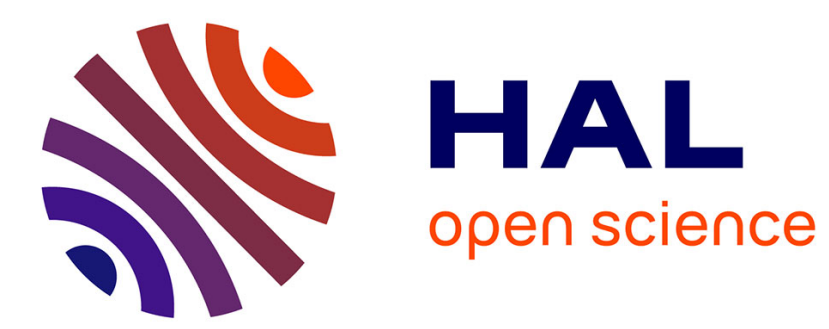

\title{
Recurrent selection for resistance to Sclerotinia sclerotiorum in sunflowers using artificial infections
}

Felicity Vear, Denis D. Tourvieille de Labrouhe

\section{To cite this version:}

Felicity Vear, Denis D. Tourvieille de Labrouhe. Recurrent selection for resistance to Sclerotinia sclerotiorum in sunflowers using artificial infections. Agronomie, 1984, 4 (8), pp.789-794. hal-00884697

\section{HAL Id: hal-00884697 \\ https://hal.science/hal-00884697}

Submitted on 1 Jan 1984

HAL is a multi-disciplinary open access archive for the deposit and dissemination of scientific research documents, whether they are published or not. The documents may come from teaching and research institutions in France or abroad, or from public or private research centers.
L'archive ouverte pluridisciplinaire HAL, est destinée au dépôt et à la diffusion de documents scientifiques de niveau recherche, publiés ou non, émanant des établissements d'enseignement et de recherche français ou étrangers, des laboratoires publics ou privés. 


\title{
Recurrent selection for resistance to Sclerotinia sclerotio- rum in sunflowers using artificial infections
}

\author{
Felicity VEAR \& Denis TOURVIEILLE DE LABROUHE* \\ I.N.R.A., Station d'Amélioration des Plantes, Domaine de Crouelle, F 63039 Clermont-Ferrand \\ *I.N.R.A. Station de Pathologie végétale, Domaine de Mon-Désir, F 63039 Clermont-Ferrand
}

Three generations of recurrent selection for Sclerotinia sclerotiorum resistance have been carried out on 2 populations of sunflower. For the first 2 cycles a test measuring the extension rate of $S$. sclerotiorum mycelium on the back of the capitulum was used. For the $3^{\text {rd }}$ cycle this test was employed together with one based on inoculation of the floral surface of the capitulum with an ascospore suspension, after which the length of the latent period until symptom appearance was measured.

From the $1^{\text {st }}$ to the $2^{\text {nd }}$ cycle, both populations showed considerable improvement. The mean of mycelium extension on the restorer population was reduced from $200 \%$ of that on control variety 'Remil' to $104 \%$ and on the maintainer population from $281 \%$ to $91 \%$. At the same time the variance was considerably reduced. However the results of the $3^{\text {rd }}$ cycle did not show any improvement. The restorer population had the same mean, $106 \%$ as in the second cycle, although with a further reduced variance and the maintainer population was slightly poorer than in the $2^{\text {nd }}$ cycle (with a mean of $113 \%$ ).

In the $3^{\text {rd }}$ cycle there was no correlation between results of the mycelium and ascospore tests. The results of the latter showed wide variation, with the population mean between those of 'Airelle' and 'Remil', so it should be possible to breed for resistance to ascospore installation. Since this test is similar to the natural cycle of $S$. sclerotiorum most weight should be given to its results.

The possible reasons for the lack of improwement with the mycelium test are discussed. It is proposed to continue the programme with a weaker selection pressure for both characters during several generations in order to determine whether real increases in $S$. sclerotiorum resistance can be obtained.

Additional key words : Test, mycelium, ascospores.

Sélection récurrente pour la résistance à Sclerotinia sclerotiorum chez le tournesol avec emploi d'infections artificielles.

Trois générations de sélection récurrente pour la résistance à Sclerotinia sclerotiorum ont été menées sur 2 populations de tournesol. Pour les 2 premiers cycles, un seul test a été appliqué, mesurant la vitesse d'extension du mycélium de Sclerotinia sur la face stérile des capitules. Pour le $3^{e}$ cycle, on a employé à la fois ce test et un autre, consistant en l'infection des faces fleuries des capitules avec une suspension d'ascospores, la variable mesurée étant le délai jusqu'à l'apparition des symptômes.

Du $1^{\text {er }}$ au $2^{\mathrm{e}}$ cycle, les 2 populations ont montré une amélioration très nette. La moyenne de la croissance mycélienne sur la population restauratrice est passée de $200 \%$ à $104 \%$ par rapport au témoin « Remil » et, sur la population mainteneuse, de $281 \%$ à $91 \%$. En même temps, la variance a été considérablement réduite. Cependant, au troisième cycle, il n'y a pas eu d'amélioration ; la population restauratrice avait la même moyenne qu'au deuxième cycle, bien qu'avec une variance encore réduite, et la sensibilité moyenne de la population mainteneuse était légèrement supérieure à celle calculée pour le $2^{e}$ cycle.

$\mathrm{Au} 3^{\mathrm{e}}$ cycle, il n'y avait pas de corrélation entre les résultats fournis par le test mycélium et par le test ascospores. Les résultats de ce dernier test montraient une variabilité importante par rapport au témoin. Il devrait donc être possible de poursuivre la sélection en utilisant ce test. Puisqu'il est plus proche du cycle naturel de Sclerotinia, il semble raisonnable de lui attribuer un poids plus élevé. Les raisons possibles des limites de l'utilisation du test mycélium sont discutées. Il sera nécessaire de poursuivre la sélection avec une pression moins élevée pour 2 caractères pendant quelques générations, afin de déterminer si de réels progrès en résistance à Sclerotinia sont possibles.

Mots clés additionnels : Test, mycélium, ascospores. 


\section{INTRODUCTION}

Sclerotinia sclerotiorum (Lib.) de Bary is probably the most important pathogen of sunflowers not controlled chemically or by complete genetic resistance, in the world as a whole, and in France in particular. However, observations of the frequency of natural attack have shown significant differences in susceptibility between genotypes (LECLERCQ, 1973 ; TOURVIEILLE \& VEAR, 1984). In different countries, different forms of attack are observed : in Canada, Romania and the U.S.A., most damage is caused by root and basal stem attack (HOES \& HUANG, 1980 ; II.IESCU : pers. comm. : ZIMMER \& FICK, 1974) ; in Yugoslavia, leaves and flower buds are attacked (CUK, 1976) ; in France and Hungary Sclerotinia disease takes the form of capitulum rot after flowering (REGNAULT et al., 1976; KURNIK et al., 1978). The relative resistance or susceptibility of sunflower genotypes to these 3 forms of attack does not appear closely related (TOURVIEILLE \& VEAR, 1984), or necessarily of the same type (CUK, 1980). Breeding for resistance to each form may thus be considered separately, although local conditions may require combined breeding programmes. The present paper deals only with capitulum rot, since this is at present the economically most damaging form in France.

In addition to significant differences between sunflower hybrids, observations of natural attack have shown significant heritable effects of parental lines (VEAR, internal report). In this case, resistance to S. sclerotiorum appeared additive for there were no significant effects of interactions between parental lines in hybrid combinations. Thus it appears possible to select for partial resistance in sunflowers.

However, in order to carry out breeding programmes, it has been necessary to develop tests useable each year, regardless of climatic conditions, to select between individual plants and families. VEAR \& GUILLAUMIN (1977) described a test using mycelium, which measured the rate of extension of $S$. sclerotiorum on sunflower capitula. Results were heritable and significantly correlated with field observations. More recently, tests using ascospores, repeating much more closely the natural cycle of $S$. sclerotiorum have been developed. First results were described by TOURVIEILLE et al. (1978) and LAMARQUE (1980) and further developed by TOURVIEILLE \& VEAR (1984).

This paper discusses the $1^{\text {st }}$ cycles of recurrent selection in sunflower populations using these mycelial and ascospore tests.

\section{MATERIAL AND METHODS}

\section{A. Sunflower populations}

Two populations, one destined to give fertility restorer «male " lines and the other male sterility maintainer « female » lines were obtained by intercrossing in isolated plots about 30 mostly unrelated genotypes in each case. These genotypes had been chosen because they, or their hybrids, showed satisfactory results in field trials or in mycelium tests. They were of Russian,
American, Canadian, Romanian and French origin. In the female population some lines with translocations from Helianthus tuberosus were included and in the male population the male parent of the control hybrid : 'Remil' was used.

\section{B. Control varieties}

These were 'Remil' the most $S$. sclerotiorum resistant hybrid so far commercialized, and 'Airelle', a rather susceptible hybrid. Results are given as percentages of those of 'Remil', whose reaction is taken as the base level for selection. 'Airelle' was used simply to verify the pathogenic activity of the inoculum.

\section{Inoculum}

The Sclerotinia sclerotiorum mycelium and ascospores are prepared according to the methods described by TOURVIEILLE \& VEAR (1984).

\section{Breeding programme}

A recurrent selection programme for $S$. sclerotiorum resistance was carried out, with alternate generations of interpollination between chosen genotypes in isolated plots without selection (when possible in a winter nursery) and self pollination and testing of a sample of about 400 plants in the summer at Clermont-Ferrand. For the interpollinations, equal quantities of seed of the chosen genotypes were mixed and sown at random in the isolated plot, at 2 dates to favorise crosses between early and late genotypes. The harvest was in bulk and the 400 plants tested constituted a random sample. Selection therefore depended entirely on individual performance. Self pollination was obtained by covering the capitulum with a sulphurised paper bag just before flowering. The tests were applied during and after flowering and the best genotypes were retained for the following generation. Although reaction to $S$. sclerotiorum was the main selection criterion, excessively tall, late or self-sterile plants were eliminated.

For the $1^{\text {st }}$ and $2^{\text {nd }}$ cycles, only the mycelium test was used. In the $3^{\text {rd }}$ cycle, an ascospore test was introduced, with comparison of 2 systems :

for the restorer population, the main stem of each plant was cut above the $1^{\text {st }}$ pair of true leaves, so that 2 axillary stems developed, each producing a capitulum with about the same flowering date. One was inoculated with ascospores in the field, while the other was harvested after flowering and inoculated with mycelium in a growth chamber (see diagram in figure 1) ;

the other method, used on the maintainer population, was to inoculate all the plants with ascospores and then, when about $70 \%$ of the plants showed symptoms, the remaining $30 \%$ were harvested and the mycelium test applied.

\section{E. Mycelium test}

This test is described in detail by VEAR \& GUILLAUMIN (1977) and TOURVIEILlE \& VEAR (1984). Three to 


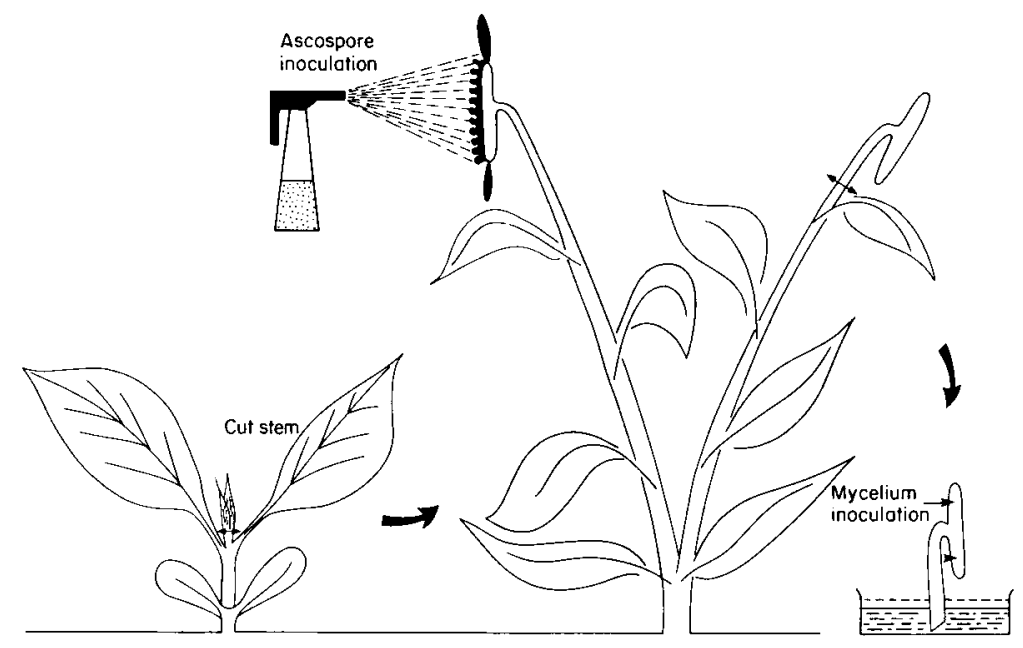

Figure 1

Diagram of inoculation of the 3rd selection cycle of the restorer population.

6 weeks after flowering, the sunflower capitula are harvested and placed in a growth chamber with their stems soaking in water at a relative humidity of $100 \%$ and a temperature of $18{ }^{\circ} \mathrm{C}$ in darkness. Three agar explants containing young $S$. sclerotiorum mycelium are placed on the back of each capitulum and the areas attacked by the fungus after 3 days are measured. The mean area of diseased spot per plant is then expressed as a percentage of the mean on the 6 control plants infected the same day.

\section{F. Ascospore test}

This test is described in detail by TOURVIEILle \& VEAR (1984).

The floral surfaces of the capitula are sprayed, during the period of anther dehiscence, with $5 \mathrm{ml}$ of a suspension of ascospores in water (concentration : 5 spores $/ \mathrm{mm}^{3}$ ). The capitula are then covered with paper bags. The plants are examined for symptoms twice a week. Resistance is measured as the number of days until disease symptoms appear on the sterile side of the capitula.
Schéma de l'inoculation des plantes du $3^{e}$ cycle de la population restauratrice.

\section{RESULTS}

\section{A. Selection for resistance by the mycelium test}

Figure 2 shows histograms of the evolution over 3 cycles of the restorer population and the control variety. In table I it may be noted that the variance of the control was reduced from cycle to cycle. This was probably due to improved techniques and the use of more exactly controlled conditions.

Although the genotypes used to constitute the population had been chosen for their useful reaction to Sclerotinia, there was considerable variation among the plants of the $1^{\text {st }}$ cycle of selection with extremes of 0 and $940 \%$ around a mean of $200.3 \%$. The 46 genotypes chosen for interpollination to give the $2^{\text {nd }}$ cycle had only $13.5 \%$ of the growth of S. sclerotiorum on 'Remil'.

There was considerable improvement from cycle 1 to cycle 2 : the mean diseased area on the plants tested was reduced from $200 \%$ of that on 'Remil' to $104 \%$ (table 1a). The variance was also reduced, much more than for 'Remil' and whereas in the $1^{\text {st }}$ cycle on

TABLE 1

Evolution of sunflower populations selected for resistance to extension of S. sclerotiorum mycelium. Evolution de 2 populations de tournesol sélectionnées pour la résistance à l'extension du mycélium de Sclerotinia.

(a) Restorer population (ISCM)

\begin{tabular}{|c|c|c|c|c|c|c|}
\hline & \multicolumn{3}{|c|}{ (a) Restorer population (ISCM) } & \multicolumn{3}{|c|}{ (b) Maintainer population (ISCF) } \\
\hline & ISCM & ISCMR 2 & ISCMR 3 & $\mathrm{ISCF}$ & ISCFR 2 & ISCFR 3 \\
\hline Plant number & 457 & 312 & 387 & 443 & 357 & 186 \\
\hline Mean $\%$ of 'Remil' & 200.3 & 104.2 & 106.8 & 281.5 & 91.4 & 112.9 \\
\hline Variance & 39966.6 & 9154.3 & 4002.9 & 123660.6 & 3605.5 & 6283.5 \\
\hline $\begin{array}{l}\% \text { of plants with more than } \\
3 \text { times extension on 'Remil' }\end{array}$ & 24.7 & 4.8 & 1.0 & 17.0 & 0.28 & 2.7 \\
\hline Mean of best 50 plants & 13.5 & 27.7 & 32.7 & 24.2 & 28.3 & 43.9 \\
\hline Variance among control plants & 1447.6 & 740.4 & 311.4 & 1447.6 & 740.4 & 311.4 \\
\hline
\end{tabular}

(b) Maintainer population (ISCF) 



Figure 2

Evolution of a restorer population during 3 cycles of recurrent selection with the mycelium test. In white, control plants.

Evolution d'une population restauratrice pendant 3 cycles de sélection récurrente avec le test mycélium. L'histogramme blanc représente les variations du témoin.

$24.7 \%$ of the plants the disease spread at least 3 times as rapidly as on 'Remil', in the $2^{\text {nd }}$ cycle this was the case for only $4.8 \%$ of the plants. However, the reduced variance was also visible among the more resistant genotypes, the 50 chosen to make up the $3^{\text {rd }}$ cycle showed more $S$. sclerotiorum growth $(27.7 \%$ of that on 'Remil') than those selected from the $1^{\text {st }}$ cycle $(13.5 \%$ ).

The $3^{\text {rd }}$ cycle did not show any improvement in the average level of resistance to $S$. sclerotiorum extension, the mean $(106 \%$ \% not being significantly different from that of the $2^{\text {nd }}$ cycle. The variance was reduced only to the same extent as that of the control but it may be noted that the mean of the best 50 plants increased to $32.7 \%$ of 'Remil'.

Figure 3 and table $1 \mathrm{~b}$ give the results for the maintainer population. From the first to the second cycle the improvement was even more spectacular than for the restorer population. Mean spread of the fungus dropped from $281 \%$ of that on 'Remil' to $91 \%$. The variance was reduced by $97 \%$ and the average extension on the 50 plants chosen for interpollination increased from $24.2 \%$ of 'Remil' in the $1^{\text {st }}$ cycle to $28.3 \%$ for the $2^{\text {nd }}$ cycle.

The $3^{\text {rd }}$ cycle showed not only no improvement but a slight reverse in the evolution of the population, the mean being $113 \%$ of 'Remil'. However, it is not entirely comparable with the other cycles since an ascospore test was applied and only the 186 plants which showed no symptoms after 30 days were tested with mycelium.
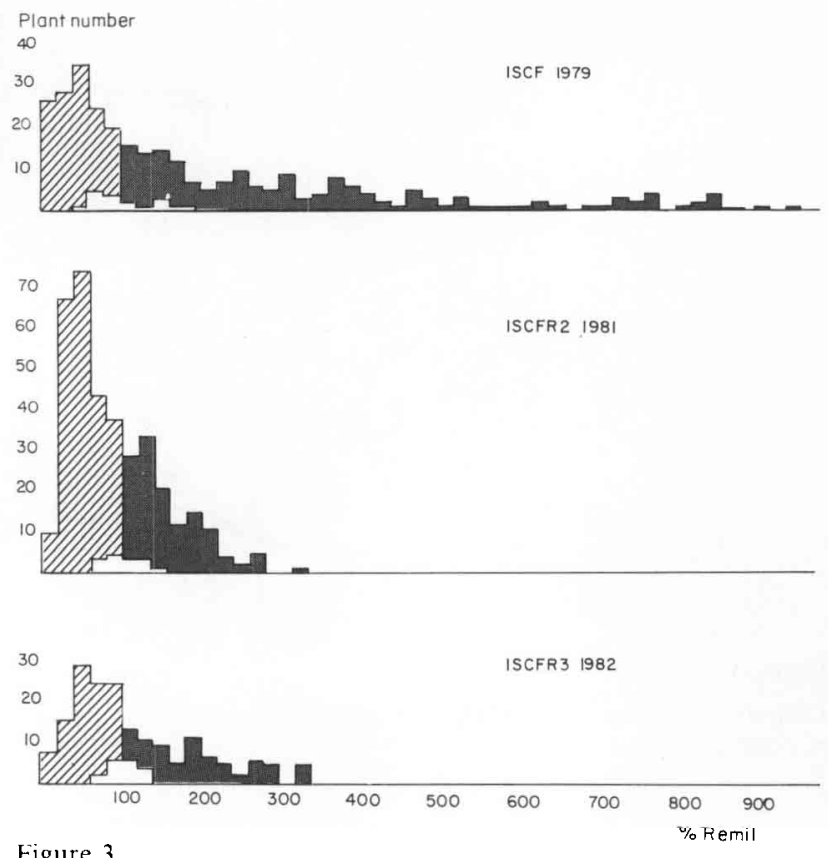

Figure 3

Evolution of maintainer population during 3 cycles of recurrent selection with the mycelium test. In white, control plants.

Evolution d'une population mainteneuse pendant 3 cycles de sélec tion récurrente avec le test mycélium. L'histogramme blanc représente les variations du témoin.

\section{B. Selection for resistance to ascospore inoculation}

The plants of the $3^{\text {rd }}$ cycle of the restorer population were inoculated with ascospores at 1 of 4 dates (July 6, 9, 13 and 16, 1982), according to their date of flowering. The delay in symptom appearance for each inoculation date is shown in figure 4 . For the

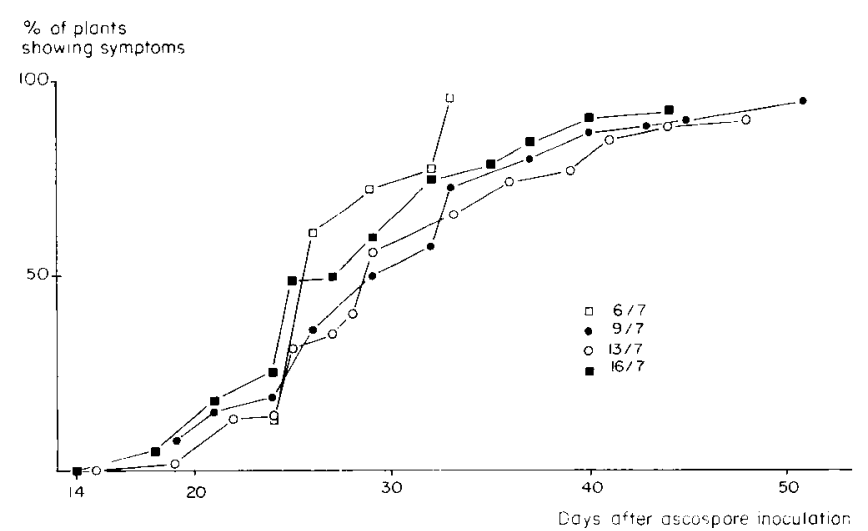

Figure 4

Appearance of Sclerotinia symptoms on the restorer population after inoculation with ascospores at 4 different dates.

Délais d'apparition des symptômes de Sclerotinia sur la population restauratrice après infection par ascospores à 4 dates différentes.

small number (18) of plants inoculated on July 6th, disease symptoms appeared more rapidly than on the plants inoculated later. This is in agreement with other results (TOUR VIEILLE \& VEAR, 1984) which suggest that the increased rate of symptom appearance is related to higher temperatures before July 10th. The closest relation between number of days after inoculation and proportion of plants showing symptoms was second 
degree $(r=0.99)$ but with a linear relation there was a very good correlation $(\mathrm{r}=0.96-0.98)$. Comparison of the linear regressions for the 3 dates shows that they are not significantly different. The results for these
3 days were therefore pooled and symptom appearance is given as number of days after inoculation. The histogram of figure 5 shows the variation from 13 to more than 50 days (after which the dry capitula were

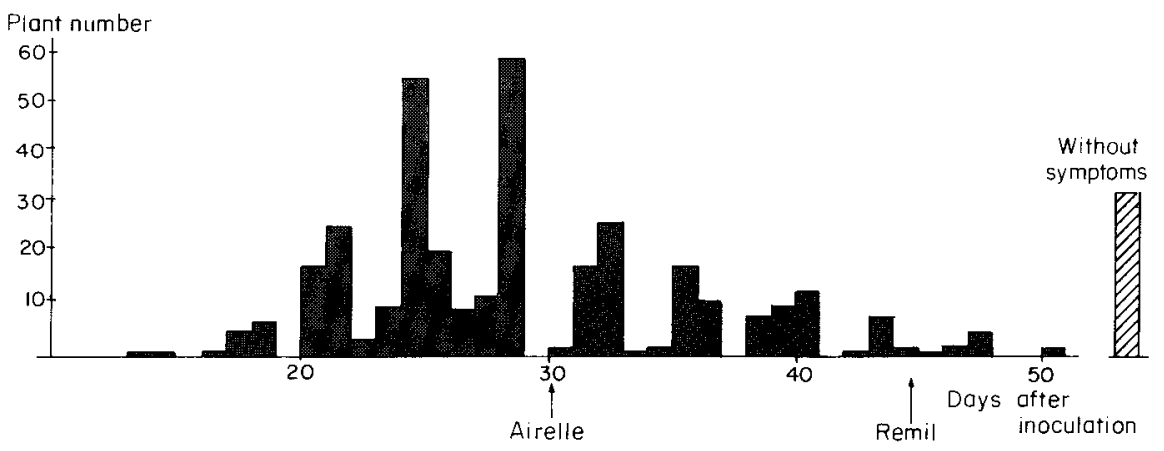

Figure 5

Appearance of symptoms on the restorer population after inoculation with ascospores in comparison with the control varieties.

harvested). The mean was 31 days above the level of 'Airelle' (28 days) but well below that of 'Remil' (42 days).

There was no significant correlation between the results of this test and those of the mycelium test applied on the pairs of capitula of each plant $(r=0.04)$. This could be due to an absence of real variation for reaction to the mycelium test. Earlier studies (TOURVIEILLE \& VEAR, 1984) showed a significant correlation between the 2 tests.

The appearance of symptoms on the plants of the maintainer population followed a similar pattern (fig. 6). The slightly earlier appearance of symptoms may be genetic, but could also be due to the different inoculation dates $(13,16,20,23$ July, 1982). When $70 \%$ of the plants inoculated at a given date showed symptoms the remaining $30 \%$ were harvested and the mycelium test was applied. The 3 days in very humid conditions in the growth chamber led to symptoms from the ascospore inoculation in only a few cases. For the $4^{\text {th }}$ cycle the plants were thus chosen from among the $30 \%$ most resistant to ascospores and with $43.9 \%$ of the mycelial growth on 'Remil'.

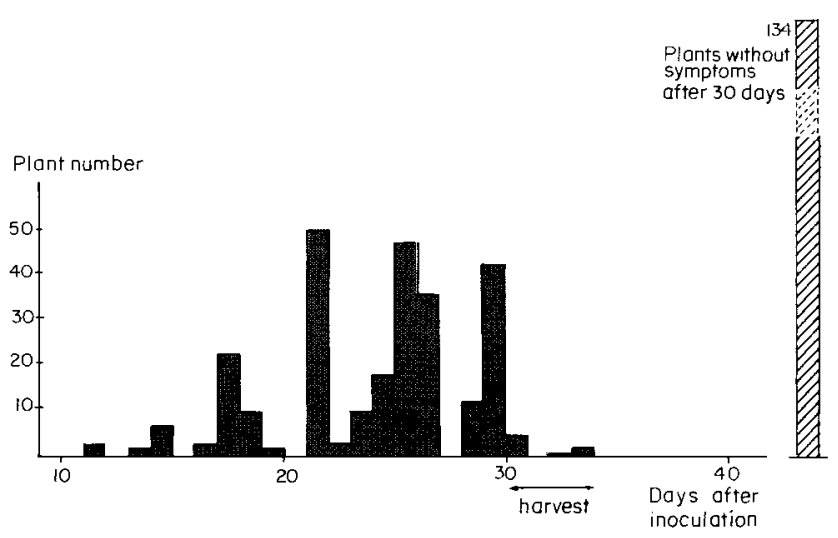

Figure 6

Appearance of symptoms on the maintainer population after inoculation with ascospores.

Apparition des symptômes sur la population mainteneuse après infection par ascospores.
Délais d'apparition des symptômes sur la population restauratrice après infection par ascospores en comparaison avec les variétés témoins.

\section{DISCUSSION}

The results reported by TOURVIEILLE \& VEAR (1984) indicate that it is possible to use the mycelium and ascospore tests each year. Thus, it should be possible to base a resistance breeding programme on them. The absence of correlation between the results of the 2 tests suggests that the characters studied may be independant so that the best programme would appear to be one using both tests concurrently in order to combine the genes necessary for each character. Since in both cases resistance is partial, addition of genes for each character should give a better total level of resistance. This idea is comparable with that of LECOQ et al. (1982) in breeding for resistance to viruses of melons, peppers and tomatoes.

However, examination of the results obtained so far suggests that it is necessary to vary the weight given and the selection intensities applied for the 2 tests.

The mycelium test has been used since 1976. That year, there was a significant correlation for 25 hybrids between the results of the test and observations of natural attack (VEAR \& GUILLAUMIN, 1977) but, in 1982, the results for 9 hybrids did not show any significant correlation (TOURVIEILLE \& VEAR, 1984). Since the test repeats only part of the $S$. sclerotiorum infection cycle, it must be used in conjunction with other tests to obtain most useful results. Nevertheless, resistance to mycelial extension is important for if symptoms appear on any present-day varieties the whole capitulum is rotted within a week and yield is lost. With sufficient resistance for the disease to spread only slowly it would be possible to harvest before complete capitulum disintegration.

During the first cycle of recurrent selection, there was a considerable improvement but this was not maintained. This could be due to phenotypic variability : while individual generations show reverse tendencies improvement is nevertheless visible over a large number of generations of selection. Such a result was obtained by LENG (1961) when selecting maize for high and low oil protein contents. Alternatively the lack of continued improvement could be genotypic, genes 
giving greater resistance to mycelium extension than those of 'Remil' either not present at all in the populations or present but linked to other less favourable genes such that their favourable effect on resistance is not discernible. The strong selection pressure applied may have resulted in too little recombination between generations of selection. This would be comparable with the problems found by MATHER \& HARRIS (1949) in the mass selection for high bristle number in Drosophila where further increases above a certain level were obtained only after stopping selection for several generations. The continued reduction in variance without any change in mean provides evidence for this.

To distinguish between the hypotheses, it is planned to continue selection for a few generations but with a reduced pressure such that a wider range of genotypes for the control of mycelial extension are included in the interpollination. If genes giving better mycelial resistance are present it should be possible to combine them gradually and they should become apparent. The reduced weight placed on the mycelial test will make it simpler to select at the same time for resistance to the ascospore test.

As might be expected from the absence of correlation, the 2 generations of selection for mycelial resistance do not appear to have any effect on the population reaction to ascospores. There is a wide variation in the length of latency with the mean situated nearer to that of 'Airelle' than that of 'Remil' but with extremes surpassing both. Selection for this character should thus be possible although heritability needs to be confirmed. Since even with only 9 genotypes the results of ascospore tests were significantly correlated with field observations (TOURVIEILLE \& VEAR, 1984) it seems reasonable to put the greatest weight on this test and select for mycelial resistance only among plants which have good ascospore resistance.

Following the problems with the $1^{\text {st }}$ generations of recurrent selection, for the $4^{\text {th }}$ cycle the 50 plants chosen were among the $40 \%$ best for the ascospore test. It remains to be seen whether a selection pressure of this type will give a slow but continued increase in resistance. It also remains to determine whether the plants that did not show symptoms escaped and give progeny which are no better than the average or are in fact highly resistant with such a delaying action on symptom appearance that they dried before the disease appeared.

Comparison of the 2 inoculation techniques indicated that both were useful but for different purposes. The technique with 2 capitula per plant was very satisfactory for comparing reactions to the 2 tests, but retarded plant development made it impossible to measure plant height and seed production and the top heavy plants were susceptible to lodging. Therefore this technique will be continued mainly for genetic studies. The technique in which the ascospore test is applied first followed by the mycelium test on the same plant has the disadvantage that it is not possible to follow appearance of symptoms for ascospore inoculation on the more resistant plants. However for a breeding programme once the selection level has been decided, when a given proportion of plants shows symptoms, those remaining can be subjected to the mycelium test without any problems and the secondary selection criterion applied.

\section{RÉFÉRENCES BIBLIOGRAPHIQUES}

Cuk L., 1976. Breeding sunflower for resistance to Sclerotinia libertiana Fuckel. Proc. 7th Int. Sunflower Conf., Krasnodar, URSS, 227-237.

Cuk L., 1980. Resistance evaluation of sunflower genotypes naturally infected by Sclerotinia sclerotiorum (Lib.) de By. Proc. 9th Int. Sunflower Conf., Malaga, Spain, 182-186.

Hoes J., Huang M., 1980. Effect of population density on development of Sclerotinia wilt and yield of sunflower. Proc. 9th Int. Sunflower Conf., Malaga, Spain, 275-280.

Kurnik E., Leranth J., Parragh J., Voros J., 1978. «Pseudo resistance " phenomenon to head rot in Hungary. Proc. 8 th Int. Sunflower Conf., Minneapolis, U.S.A., 271-279.

Lamarque C., 1980. Obtention d'ascospores de Sclerotinia sclerotiorum et techniques d'inoculation utilisables dans la sélection variétale de tournesol. Informations techniques CETIOM, 71, 22-27.

Leclercq P., 1973. Influence des facteurs héréditaires sur la résistance apparente du tournesol à Sclerotinia sclerotiorum. Ann. Amélior. Plant., 23, 279-286.

Lecoq H., Pochard E., Pitrat M., Laterrot H., Marchoux G., 1982. Identification et exploitation de résistances aux virus chez les plantes maraîchères. Cryptogam. Mycol., 3, 333-345.
Leng E., 1961. Predicted and actual responses during long term selection for chemical composition in maize. Euphytica, 10, 368-378.

Mather K., Harrison B., 1949. The manifold effects of selection. Heredity, 3, 131.

Regnault et al., 1976. Répartition des principales maladies du tournesol en France. Proc. 7th Int. Sunflower Conf., Krasnodar, URSS, 179-188.

Tourvieille de Labrouhe D., Guillaumin J. J., Vear F., Lamarque C., 1978. Rôle des ascospores dans l'infection du tournesol par Sclerotinia sclerotiorum (Lib.) de By. Ann. Phytopathol., 10, 417-431.

Tourvieille de Labrouhe D., Vear F., 1984. Comparaison de méthodes d'estimation de la résistance du tournesol au Sclerotinia sclerotiorum (Lib.) de By. Agronomie, 4 (6).

Vear F., Guillaumin J. J., 1977. Etude de méthodes d'inoculation de tournesol par Sclerotinia sclerotiorum et application à la sélection. Ann. Amélior. Plant., 27, 523-537.

Zimmer D., Fick G., 1974. Some diseases of sunflowers in the United-States - their occurrence, biology and control. Proc. 6th Int. Sunflower Conf., Bucharest, Rumania, 673-680. 